\title{
ע Tulevien vanhempien alkoholinkäyttö raskausaikana
}

Tutkimuksessa kuvataan tulevien vanhempien alkoholinkäyttöä raskausaikana. Tutkimusaineisto kerättiin vuoden 2012 aikana lastaan odottavilta tulevilta äideiltä ja heidän puolisoiltaan. Tutkimukseen osallistui 380 perhettä. Tutkimusaineistoa käsiteltiin ristiintaulukoinnin avulla ja kuvattiin tarkastelemalla vastausten frekvenssejä sekä prosenttiosuuksia. Yli puolet raskaana olevista tulevista äideistä käytti alkoholia raskausaikana. Suurin osa raskausaikana alkoholia käyttävistä naisista käytti alkoholia harvoin ja pieniä määriä kerralla, vaikka lähes neljännes käytti kerralla vähintään kolme alkoholiannosta. Runsaasti alkoholia raskausaikana käytti lähes viisi prosenttia tulevista äideistä. Enemmistö puolisoista käytti alkoholia kohtuullisesti. Lähes puolet käytti alkoholia korkeintaan kerran kuukaudessa ja hieman yli puolet käytti kerralla yksi-neljä alkoholiannosta. Runsaasti alkoholia käytti noin seitsemän prosenttia puolisoista ja reilu 12 prosenttia heistä oli raittiita. Tulevien vanhempien arviot toistensa alkoholin käytöstä olivat melko yhteneväiset. Vanhempien kanssa on tärkeä keskustella alkoholinkäytöstä, sen vaikutuksista lapsiin ja mahdollisista haitoista lapselle ja perheen arjelle esimerkiksi neuvolassa. Raskaana olevien naisten alkoholinkäytön yleisyyttä tulisi myös kartoittaa laajemmin Suomessa. Olisi myös mielenkiintoista selvittää, miksi suomalaiset naiset käyttävät alkoholia raskausaikana, vaikka virallisissa ohjeistuksissa tulevia äitejä ohjeistetaan pidättäytymään alkoholista raskausaikana.

ASIASANAT: lapsiperhe, alkoholin käyttö, raskausaika

JENNI KOMULAINEN, SARI LEPISTÖ, MIKA HELMINEN, JARI KYLMÄ, EIJA PAAVILAINEN

\section{JOHDANTO}

Eurooppalainen ja pohjoismainen alkoholipolitiikka ovat lähentyneet toisiaan viimeisen 20 vuoden aikana. Pohjoismaista alkoholipolitiikka on vapautunut eniten Suomessa. (1.) Aiemmin Suomessa lähinnä miehet käyttivät alkoholia (2). Yhteiskunnan tasa-arvoistumisen myötä suhtautuminen naisten alkoholinkäyttöön on kuitenkin muuttunut sallivammaksi, ja naisten ja miesten käyttötottumukset ovat lähentyneet toisiaan (3).

Alkoholipolitiikan vapautumisen, ihmisten vapaa-ajan lisääntymisen, toimeentulon parantumisen sekä yhteiskunnan tasa-arvoistumisen ja kaupungistumisen myötä suomalaisten alkoholinkulutus on lisääntynyt viimeisen 50 vuoden aikana kahta poikkeusta lukuun ottamatta. 1990-luvun talouslama vähensi suomalaisten alkoholinkulutusta noin kymmenellä prosentilla ja vuoden 2008 jälkeen suomalaisten alkoholin kokonaiskulutus on kääntynyt loivaan laskuun taloudellisen kasvun heikkeneminen ja alkoholiveron korotusten myötä. Tällä hetkellä suomalaisten alkoholin kokonaiskulutus on Eurooppalaisessa mittakaavassa ylempää keskitasoa. $(4,5$.)

Muutos on ollut erityisen merkittävä naisten alkoholinkulutuksessa: naisten kuluttaman alkoholin osuus on kasvanut 12 prosentista 26 prosenttiin neljän viimeisen vuosikymmenen aikana ja naiset ovat 1990-luvulta lähtien kuluttaneet neljänneksen kaikesta Suomessa kulutetusta alkoholista. Eniten alkoholin kokonaiskulutus on lisääntynyt yli 50-vuotiailla miehillä ja yli 30-vuotiailla naisilla. Naisista 30-49 vuotiaat 
käyttivät vuonna 2008 saman verran alkoholia kuin miehet keskimäärin vuonna 1968. (6.) Myös perhettä suunnittelevien naisten alkoholinkäyttö on lisääntynyt, ja 90 prosenttia hedelmällisessä iässä olevista naisista käyttää alkoholia (7).

Alkoholinkäyttö raskausaikana on aina iso riski, ja alkoholi on todistetusti sikiölle haitallinen aine. Alkoholin nauttiminen raskausaikana voi johtaa raskauden keskeytymiseen, synnytyksen ennenaikaiseen käynnistymiseen tai sikiön kasvun ja keskushermoston pysyvään vaurioitumiseen. Alkoholinkäyttö raskausaikana voi aiheuttaa lapselle monimuotoisen oirekuvan, josta käytetään nimitystä FASD eli Fetal Alcohol Spectrum Disorders. (8.) Kansainvälisen arvion mukaan FASD-oireyhtymää esiintyy länsimaissa 1,4-5 prosentilla väestöstä (9-11). Arvioiden mukaan Suomessa syntyy vuosittain noin 550-600 lasta, joilla todetaan FASD. (7.) Todellisuudessa alkoholin vaurioittamia lapsia syntyy yllä olevaa arviota enemmän, koska valtaosaa alkoholialtistuksen aiheuttamista sikiövaurioista ei voida tunnistaa ulkoisten piirteiden avulla (12).

Tarkkaa sikiövaurioita aiheuttavaa alkoholimäärä ei tiedetä, mutta sikiön vaurioitumisen riski kasvaa sitä enemmän, mitä useammin ja mitä suurempia määriä alkoholia tuleva äiti käyttää raskaana ollessaan. (7.) Tutkimukset osoittavat, että etenkin runsas humalahakuinen alkoholinkäyttö (yli kuusi alkoholiannosta kerralla) ensimmäisen raskauskolmanneksen aikana on yhteydessä lapsen kognitiivisten toimintojen häiriöihin $(13,14)$, lisää sikiön epämuodostumisen riskiä (15) ja johtaa poikkeavuuksiin keskushermoston kehityksessä (16.). Kohtuullisen tai vähäisen raskaudenaikaisen alkoholinkäytön vaikutuksista sikiön kehitykseen on saatu tutkimuksissa ristiriitaisia tuloksia $(17,18)$.

Yhteys runsaan raskaudenaikaisen alkoholinkäytön ja lapsen FASD-oireyhtymän välillä on voitu osoittaa mittaamalla alkoholinkäytön biomarkkereita (19) ja kysymällä tulevalta äidiltä tämän alkoholinkäytöstä (15). Tulevan äidin matalampi sosioekonominen tausta yhdessä runsaan alkoholin käytön kanssa lisää lapsen riskiä sairastua FASD-oireyhtymään (20). Matalan sosioekonomisen taustan omaavilla äideillä on usein myös muita sikiön tervettä kehitystä uhkaavia ongelmia, kuten tupakointi, heikot sosiaaliset olosuhteet (21) ja aliravitsemus (22).

\section{TUTKIMUKSEN TAUSTA}

Raskaana olevien naisten alkoholinkäyttöä kartoittavia tutkimuksia haettiin Cinahl-, Medline-, Pubmed- ja PsycInfo-tietokannoista syksyn 2015 aikana. Naisten raskaudenaikaisesta alkoholin käytöstä löytyi paljon tutkittua tietoa. Tähän kirjallisuuskatsaukseen valittiin tutkimuksia, jotka on toteutettu Pohjoismaissa tai Länsi-Euroopassa, joissa yleinen alkoholinkäyttökulttuuri on lähellä suomalaista kulttuuria.

Tarkkaa tietoa suomalaisten naisten raskaudenaikaisesta alkoholin käytön yleisyydestä ja määristä ei ole saatavilla (23). Viitteitä aiheesta tarjoaa Nordströmin ja kollegoiden (24) tutkimus, jossa kartoitettiin lasten käytöshäiriöiden ja ADHD:n (attention deficit hyperactivity disorder) riskitekijöitä. Tutkimuksessa alkoholia käytti raskausaikana 55 prosenttia tulevista äideistä. Viimeisin Suomessa toteutettu tulevien äitien päihteiden käyttöä kartoittava tutkimus on Pajulon ja kollegoiden tutkimus 1990-luvun lopulta. Tutkimuksen mukaan kuudella prosentilla raskaana olevista naisista oli päihderiippuvuus eli alkoholin, huumeiden tai lääkkeiden väärinkäyttöä. (25.)

Kansainvälisissä tutkimuksissa naisten alkoholinkäyttö raskausaikana vaihtelee paljon. Tutkimustulosten mukaan alkoholia käyttää raskausaikana 5,5-45,0 prosenttia tulevista äideistä. Valtaosa raskausaikana alkoholia käyttävistä naisista käyttää kuitenkin alkoholia vain satunnaisesti ja pieniä määriä kerralla. (26-33.) Humalahakuisesti raskausaikana alkoholia käyttävien naisten määrä vaihtelee aiemmissa tutkimuksissa 0,4 ja 17,0 prosentin välillä $(26,28)$.

Tutkimuksissa vanhemmat naiset käyttivät raskausaikana alkoholia nuorempia naisia useammin $(28,30,31,33)$. Korkeasti koulutetut ja korkean sosioekonomisen taustan omaavat naiset käyttivät tutkimuksissa enemmän alkoholia raskausaikana kuin matalan koulutuksen ja sosioekonomisen taustan omaavat tulevat äidit (28-31,33). Raskaudenaikainen alkoholinkäyttö oli runsaampaa naisilla, joilla oli entuudestaan yksi tai useampi lapsi kuin ensimmäistä lastaan odottavilla naisilla $(26,28,33)$.

Tulevien isien alkoholin käytöstä puolison raskausaikana on hyvin vähän tutkimustietoa, vaikka lapsen kasvun turvaaminen sikiöaikana on vanhempien yhteinen tehtävä. Tiedossa on myös, että ei-raskaana olevalla vanhemmalla on 
keskeinen rooli raskaana olevan puolison tukijana ja että alkoholin käytön vähentäminen on tulevalle äidille paljon vaikeampaa, jos alkoholi on vahvasti esillä perheen arjessa. (7.)

Terveyden ja hyvinvoinnin laitoksen (THL) vuonna 2008 suorittaman valtakunnallisen kyselyn mukaan suomalaisista miehistä kymmenen prosenttia oli raittiita ja kahdeksan prosenttia ylitti alkoholin suurkulutuksen rajan (4). Suomessa vuonna 1992 tehdyssä tutkimuksessa 32 prosenttia miehistä vähensi alkoholinkäyttöä puolisonsa raskausaikana. Tutkimuksessa miehen korkea koulutustausta lisäsi alkoholin käyttökertojen määrää, mutta kerralla käytetyt alkoholimäärät olivat pienempiä kuin matalamman koulutustaustan omaavilla miehillä. Matalasti koulutetut miehet käyttivät alkoholia harvemmin, mutta kerralla kulutetut määrät olivat suurempia kuin korkeasti koulutetuilla miehillä. (34.) Alle 30-vuotiaat miehet käyttivät alkoholia humalahakuisesti useammin kuin heitä vanhemmat miehet, kun taas alle 30-vuotiaista miehistä hieman suurempi osa oli raittiita (4).

Tutkimukset osoittavat, että vanhempien alkoholinkäyttö on yhteydessä lapsen kaltoinkohteluun ja sen on osoitettu lisäävän etenkin lapsen fyysisen pahoinpitelyn todennäköisyyttä. Runsaan alkoholinkäytön ohella myös alkoholin kohtuukäytön on osoitettu lisäävän vanhempien todennäköisyyttä kohdella lastaan kaltoin. (35.) Etenkin äidin runsaalla alkoholinkäytöllä pikkulapsiaikana (36) sekä äidin raskaudenaikaisella alkoholinkäytöllä (37) on selkeä yhteys lapsen kaltoinkohteluun ja sen riskin lisääntymiseen.

Suomessa vanhempien alkoholinkäyttöä kartoitetaan äitiysneuvolassa AUDIT-kyselyllä (Alcohol Use Disorders Identification Test) (39), ja äitiysneuvolat ovatkin keskeisessä asemassa päihdeongelmaisten perheiden tunnistamisessa, hoidossa ja hoitoonohjauksessa (7). Äitiysneuvolassa tulevaa äitiä ohjeistetaan lopettamaan alkoholinkäyttö kokonaan viimeistään raskauden varmistuttua, ja myös tulevan isän alkoholinkäyttöä kartoitetaan puolison raskausaikana (38).

\section{TUTKIMUKSEN TARKOITUS JA TUTKIMUSKYSYMYKSET}

Tutkimuksen tarkoitus on kuvata lasta odottavien vanhempien alkoholinkäyttöä raskausaikana. Tutkimuksella saadaan ajankohtaista tietoa tulevien vanhempien alkoholinkäyttötottumuk- sista Suomessa. Tutkimustuloksia voidaan hyödyntää terveydenhuollossa perheiden riskiolojen ja niistä johtuvan tuen tarpeen tunnistamisessa. Tutkimuskysymykset ovat:

1. Millaista on lasta odottavien vanhempien alkoholinkäyttö raskausaikana?

2. Miten taustamuuttujat ikä, aiempien lasten lukumäärä, koulutus, kohonnut kaltoinkohtelun riski CAP-mittarilla mitattuna, vaikeus puhua perheen asioista, huoli omasta alkoholin käytöstä ja huoli puolison alkoholin käytöstä ovat yhteydessä tulevien vanhempien alkoholinkäyttöön raskausaikana?

3. Miten vastaajan oma kuvaus alkoholin käytöstä tulevan äidin raskausaikana eroaa siitä, miten puoliso kuvaa hänen alkoholinkäyttöään?

4. Miten taustamuuttujat vaikeus puhua perheen asioista ja kohonnut kaltoinkohtelun riski CAP-mittarilla mitattuna ovat yhteydessä vanhempien kuvaukseen toistensa alkoholinkäytöstä?

\section{MENETELMÄT}

\section{AINEISTO}

Tutkimusaineisto kerättiin kahden maakunnan alueella vuoden 2012 aikana raskaana olevilta naisilta ja heidän puolisoiltaan raskausviikolla 30. Aineisto kerättiin terveydenhoitajien neuvoloissa toteuttamilla kyselyillä. Neuvoloihin toimitettiin yhteensä 1200 kyselylomaketta. Kysely jaettiin 763 perheelle, joista 380 perhettä vastasi kyselyyn (vastausprosentti 52). Tulevista äideistä 59 vastasi kyselyyn ilman puolisoa ja puolisoista 20 vastasi ilman tulevaa äitiä. Heidän kohdallaan alkoholinkäyttöä ja siihen yhteydessä olevia taustamuuttujia tarkasteltiin vain vastaajan omien vastausten osalta.

\section{MITTARIT}

Vanhempien alkoholinkäyttöä kartoitettiin kyselyssä AUDIT-mittarilla, jossa vastaajaa pyydetään kertomaan kuinka usein hän itse ja hänen puolisonsa nauttii olutta, viiniä tai muita alkoholijuomia. Vastausvaihtoehdot alkoholin käyttökertojen määrän kuvaamiseen olivat: a) ei koskaan, b) kerran kuukaudessa tai harvemmin, 
c) kahdesta neljään kertaa kuukaudessa, d) kahdesta kolmeen kertaa viikossa ja e) neljä kertaa viikossa tai useammin. (39.) Tulevan äidin alkoholin käyttökertojen määrää kuvaava muuttuja luokiteltiin analyysia varten kolmeluokkaiseksi: 1) ei käytä, 2) käyttää kerran kuukaudessa tai harvemmin ja 3) käyttää kaksi kertaa kuukaudessa tai useammin. Puolisoiden vastaava muuttuja luokiteltiin myös kolmeluokkaiseksi: 1) käyttää kerran kuukaudessa tai harvemmin, 2) käyttää kaksi-neljä kertaa kuukaudessa ja 3) käyttää kaksi kertaa viikossa tai useammin.

Kerralla nautittujen alkoholiannosten määrä pyydettiin kyselyssä merkitsemään numeerisesti. Kyselyssä ei määritelty alkoholiannosta. Tulevien äitien kerralla käyttämää alkoholimäärää kuvaava muuttuja luokiteltiin neljäluokkaiseksi: 1) ei käytä, 2) käyttää yksi-kaksi annosta, 3) käyttää kolme-kuusi annosta ja 4) käyttää seitsemän annosta tai enemmän. Puolisoiden kohdalla vastaava muuttuja luokiteltiin seuraavasti: 1) ei käytä, 2) käyttää yksi-neljä annosta, 3) käyttää viisi-kymmenen annosta ja 4) käyttää 11 annosta tai enemmän.

Alkoholinkäyttöä kuvaavat muuttujat luokiteltiin eri tavalla tulevien äitien kuin puolisoiden ryhmässä, koska raskaana olevien naisten kohdalla satunnainen sekä määrällisesti vähäinenkin alkoholinkäyttö voi olla merkityksellistä sikiön kehityksen kannalta, ja virallisena ohjeistuksena onkin pidättäytyä alkoholista raskausaikana kokonaan (40). Puolisoiden kohdalla taas haluttiin erottaa säännöllisesti ja runsaasti alkoholia käyttävät vastaajat niistä, jotka käyttävät alkoholia vain satunnaisesti tai eivät ollenkaan.

Vastaajia pyydettiin kuvaamaan kyselyssä puolison alkoholin käyttökertojen määrää ja kerralla käytettyä alkoholimäärää samoilla vastausvaihtoehdoilla kuin omaa alkoholinkäyttöään. Puolison alkoholinkäyttöä kuvaavat muuttujat luokiteltiin niin tulevien äitien kuin heidän puolisoidensa ryhmässä seuraavasti: 1) vastaus merkittävästi pienempi kuin puolison (vastaus vähintään kaksi luokkaa pienempi), 2) vastaus hieman pienempi kuin puolison (vastaus yhden luokan pienempi), 3) vastaus sama kuin puolison, 4) vastaus hieman suurempi kuin puolison (vastaus yhden luokan suurempi) ja 5) vastaus merkittävästi suurempi kuin puolison (vastaus vähintään kaksi luokkaa suurempi).
Tutkimuksen taustamuuttujat valittiin seuraavasti. Ikä $(28,30,31,33)$ ja koulutustausta (28-31,33,34) valittiin taustamuuttujiksi, koska aiempi tutkimus on osoittanut niillä olevan yhteyden tulevien vanhempien alkoholinkäyttöön raskausaikana. Aiempien lasten lukumäärä valittiin tarkasteluun, koska aiempi tutkimus on osoittanut sillä olevan yhteyden tulevien äitien raskaudenaikaiseen alkoholinkäyttöön $(26,28,33)$. Kohonnut kaltoinkohteluriski valittiin, koska aiempi tutkimus on osoittanut vanhempien alkoholin käytön lisäävän lapsen kaltoinkohteluriskiä (35-37). Muut taustamuuttujat valittiin, koska niillä oletettiin olevan yhteys tulevien vanhempien alkoholinkäyttöön raskausaikana. Vaikeutta puhua perheen asioista ulkopuolisille sekä kaltoinkohtelun riskiä tarkasteltiin suhteessa vanhempien arvioihin toistensa alkoholin käytöstä.

Kyselyssä ikä selvitettiin kysymällä vastaajan syntymävuotta. Analyyseja varten vastaajien ikä luokiteltiin sekä tulevien äitien että puolisoiden ryhmässä kaksiluokkaiseksi: 1) alle 31-vuotiaat ja 2) 31-vuotiaat tai sitä vanhemmat. Koulutustaustaa kuvaava muuttuja luokiteltiin kolmeluokkaiseksi: 1) peruskoulu tai lukio, 2) ammatillinen tutkinto ja 3) yliopisto tai korkeakoulu. Aiempien lasten lukumäärän kartoittamiseksi vastaajia pyydettiin kertomaan, kuinka monta lasta heidän perheeseensä kuuluu. Lasten lukumäärää kuvaava muuttuja luokiteltiin tutkimusta varten kolmeluokkaiseksi: 1) ei lapsia, 2) yksi lapsi ja 3) kaksi lasta tai enemmän.

Lapsen kaltoinkohtelun riskiä kartoitettiin kyselyssä Child Abuse Potential Inventory (CAP) -mittarilla (41). Mittari sisälsi 160 kysymystä, joiden vastausvaihtoehtoina olivat: a) olen samaa mieltä ja b) olen eri mieltä. Kaltoinkohteluriskiä kuvaava muuttuja luokiteltiin kaksiluokkaiseksi: 1) ei riskiä (0-99 pistettä) ja 2) kohonnut riski (100 pistettä tai enemmän). CAP-mittarin validiteetti on testattu osana tutkimushanketta. Mittarin sisäinen yhteneväisyys vaihteli välillä 0,88-0,91. (42.) Riskipisteet luokiteltiin analyysia varten seuraavasti: 1 ) ei riskiä (0-99 pistettä) ja 2) kohonnut riski (100 pistettä tai enemmän). Tutkimusta varten huolta omasta ja puolison alkoholinkäytöstä kuvaava muuttuja luokiteltiin kaksiluokkaiseksi: 1) on huolissaan ja 2) ei ole huolissaan. 


\section{TILASTOLLISET ANALYYSIT}

Aineistoa käsiteltiin erikseen tulevan äidin ja puolison osalta. Aineistoa kuvattiin tarkastelemalla vastausten frekvenssejä ja prosenttiosuuksia. Alkoholin käyttökertojen määrän sekä kerralla käytetyn alkoholimäärän ja taustamuuttujien välisiä yhteyksiä tarkasteltiin ristiintaulukoinnin avulla. Jakaumaerojen tilastollista merkitsevyyttä testattiin khiin neliö -testillä ja tilastollisen merkitsevyyden rajana pidettiin $\mathrm{p}<0,05$. Tilastollista merkitsevyyttä testattiin Fisherin tarkalla testillä pienissä aineistoissa, joissa yli 20 prosenttia odotetuista frekvensseistä oli alle viisi tai jokin odotettu frekvenssi oli alle yksi. Myös puolisoiden arvioita toistensa alkoholin käytöstä ja niissä ilmenevien eroavaisuuksien suhdetta taustamuuttujiin tarkasteltiin ristiintaulukoinnin avulla. Jakaumaerojen tilastollista merkitsevyyttä testattiin Fisherin tarkalla testillä, koska muuttujien luokkien frekvenssit olivat pieniä. Aineisto analysoitiin IBM SPSS 23.0 -tilastonkäsittelyohjelmalla. (43.)

\section{TULOKSET}

\section{VASTAAJIEN TAUSTATIEDOT}

Yhtä perhettä lukuun ottamatta kaikkien raskaana olevien naisten puolisot olivat miehiä. Suurin osa tulevista äideistä oli iältään 25-35 -vuotiaita, kun taas puolisoista enemmistö oli yli 31-vuotiaita. Raskaana olevista naisista lähes puolet oli suorittanut korkeakoulututkinnon, kun taas puolisoista suurin osa oli suorittanut ammatillisen tutkinnon. Kolmasosa sekä raskaana olevista naisista että heidän puolisoistaan odotti ensimmäistä lastaan, ja kolmasosalla oli yksi aiempi lapsi. Riski kohdella lasta kaltoin esiintyi vajaalla viidenneksellä tulevista äideistä ja noin seitsemällä prosentilla puolisoista. Tulevista äideistä noin seitsemän prosenttia ja puolisoista noin kymmenen prosenttia koki vaikeaksi puhua perheen asioista ulkopuolisille. Yksikään raskaana oleva nainen itse tai yksikään puoliso ei ollut huolissaan tulevan äidin alkoholinkäytöstä. Puolison alkoholinkäytöstä oli huolissaan kahdeksan prosenttia tulevista äideistä ja muutama prosentti puolisoista itsestään. Vastaajien taustatiedot on kuvattu taulukossa 1.

\section{TULEVAN ÄIDIN ALKOHOLINKÄYTTÖ RASKAUSAIKANA JA ALKOHOLINKÄYTTÖÖN YHTEYDESSÄ OLEVAT TAUSTAMUUTTUJAT}

Yli puolet naisista käytti alkoholia raskausaikana. Suurin osa alkoholia raskausaikana käyttävistä naisista nautti yhden tai kaksi annosta kerralla. Alle viisi prosenttia tulevista äideistä käytti alkoholia yli kuusi annosta kerralla.

Tulevien äitien raskaudenaikaiseen alkoholinkäyttöön oli tilastollisesti merkitsevästi yhteydessä taustamuuttujat: aiempien lasten lukumäärä perheessä $(\mathrm{p}=0,028)$ ja tulevan äidin koulutustausta $(\mathrm{p}=0,021)$. Ensimmäistä lastaan odottavat naiset käyttivät suurempia alkoholimääriä kerralla kuin naiset, joilla oli lapsia entuudestaan. Alkoholista täysin pidättäytyvien osuus oli suurin tulevilla äideillä, joilla oli yksi aiempi lapsi.

Matalasti koulutetut raskaana olevat naiset käyttivät suurempia alkoholimäärï kerralla kuin korkeasti koulutetut naiset. Kohtuullisesti (yksi-kaksi annosta) alkoholia käyttäviä oli eniten korkeasti koulutettujen tulevien äitien ryhmässä. Pelkän peruskoulun tai lukion suorittaneissa naisissa oli eniten täysin raskausaikana alkoholista pidättäytyviä. Raittiiden naisten osuus oli pienin korkeasti koulutettujen tulevien äitien ryhmässä.

Raskaana olevan naisen oman ja puolison huolen yhteyttä tulevan äidin alkoholinkäyttöön ei voitu testata, koska kukaan raskaana oleva äiti itse tai heidän puolisonsa ei ollut huolissaan tulevan äidin alkoholinkäytöstä. Taulukossa 2 on esitetty tulevien äitien alkoholin käyttökertojen määrän ja kerralla käytetyn alkoholimäärän yhteys taustamuuttujiin.

\section{PUOLISON ALKOHOLINKÄYTTÖ RASKAUSAIKANA JA ALKOHOLINKÄYTTÖÖN YHTEYDESSÄ OLEVAT TAUSTAMUUTTUJAT}

Suurin osa puolisoista käytti alkoholia kerran kuukaudessa tai harvemmin. Puolisoista yli puolet käytti kerralla yksi-neljä annosta, vajaa kolmannes viisi-kymmenen annosta ja alle kymmenesosa käytti alkoholia 11 annosta tai enemmän. Täysin raittiita oli 12 prosenttia kaikista puolisoista.

Puolisoiden alkoholinkäyttöön tulevan äidin raskausaikana oli tilastollisesti merkitsevästi yhteydessä taustamuuttujat: Ikä $(\mathrm{p}=0,016)$, aiempien lasten lukumäärä perheessä $(\mathrm{p}=0,001)$, koulutustausta $(\mathrm{p}=0,007)$, tuleva isä huolis- 
Taulukko 1. Vastaajien taustatiedot $(\mathrm{N}=380)$.

\begin{tabular}{|c|c|c|c|c|c|}
\hline \multirow[t]{2}{*}{ Muuttuja } & & \multicolumn{2}{|c|}{ Äiti } & \multicolumn{2}{|c|}{ Puoliso } \\
\hline & & $\mathrm{n}$ & $(\%)$ & $\mathrm{n}$ & $(\%)$ \\
\hline \multirow[t]{2}{*}{ Sukupuoli } & nainen & 360 & $(94,7)$ & 1 & $(0,3)$ \\
\hline & mies & 0 & $(0)$ & 300 & $(78,9)$ \\
\hline \multirow[t]{4}{*}{ Ikä } & alle 25 vuotias & 48 & $(12,6)$ & 21 & $(5,5)$ \\
\hline & $25-30$ vuotias & 115 & $(30,0)$ & 75 & $(19,7)$ \\
\hline & $31-35$ vuotias & 120 & $(31,6)$ & 112 & $(29,5)$ \\
\hline & yli 35 vuotias & 76 & $(20,0)$ & 93 & $(24,5)$ \\
\hline \multirow[t]{5}{*}{ Lasten lukumäärä } & ei lapsia & 136 & $(35,8)$ & 115 & $(30,8)$ \\
\hline & yksi & 141 & $(37,1)$ & 113 & $(29,7)$ \\
\hline & kaksi & 61 & $(16,1)$ & 57 & $(15,0)$ \\
\hline & kolme & 11 & $(2,9)$ & 8 & $(2,1)$ \\
\hline & yli neljä & 11 & $(2,9)$ & 7 & $(1,8)$ \\
\hline \multirow[t]{4}{*}{ Korkein koulutus } & peruskoulu & 13 & $(3,4)$ & 23 & $(6,1)$ \\
\hline & lukio & 23 & $(6,1)$ & 20 & $(5,3)$ \\
\hline & ammatillinen tutkinto & 144 & $(37,9)$ & 164 & $(43,7)$ \\
\hline & yliopisto tai korkeakoulu & 176 & $(46,3)$ & 93 & $(24,5)$ \\
\hline \multirow[t]{2}{*}{ Kohonnut kaltoinkohtelun riski } & ei & 299 & $(78,7)$ & 280 & $(73,7)$ \\
\hline & kyllä & 61 & $(16,1)$ & 25 & $(6,6)$ \\
\hline \multirow[t]{2}{*}{ Vaikeus puhua perheen asioista } & ei & 331 & $(87,1)$ & 257 & $(67,6)$ \\
\hline & kyllä & 28 & $(7,4)$ & 43 & $(11,3)$ \\
\hline \multirow[t]{3}{*}{ Huolissaan omasta alkoholinkäytöstä } & ei & 358 & $(94,2)$ & 292 & $(76,8)$ \\
\hline & vähän & 0 & $(0,0)$ & 8 & $(2,1)$ \\
\hline & paljon & 0 & $(0,0)$ & 1 & $(0,3)$ \\
\hline \multirow[t]{3}{*}{ Huolissaan puolison alkoholinkäytöstä } & ei & 322 & $(84,7)$ & 302 & $(79,5)$ \\
\hline & vähän & 28 & $(7,4)$ & 0 & $(0,0)$ \\
\hline & paljon & 3 & $(0,8)$ & 0 & $(0,0)$ \\
\hline
\end{tabular}

saan omasta alkoholinkäytöstään $(\mathrm{p}=0,026)$, $(\mathrm{p}=0,017)$, puoliso huolissaan tulevan isän alkoholinkäytöstä $(\mathrm{p}=0,001)$ ja vaikeus puhua perheen asioista $(\mathrm{p}=0,048)$.

Alle 31-vuotiaat puolisot käyttivät suurempia määriä alkoholia kerralla kuin heitä vanhemmat puolisot. Enemmistö sekä alle 31-vuotiasta että yli 31-vuotiaista puolisoista käytti kerralla yksineljä alkoholiannosta. Yli kymmenen annosta kerralla käyttäviä puolisoita oli hieman enemmän alle 31-vuotiaiden keskuudessa.

Kerralla käytetty alkoholimäärä oli suurin puolisoilla, joilla ei ollut aiempia lapsia. Ensimmäistä lastaan odottavista puolisoista lähes
40 prosenttia käytti alkoholia yksi-neljä annosta kerralla ja yhtä suuri osa käytti alkoholia viisikymmenen annosta kerralla. Valtaosa puolisoista, joilla oli entuudestaan yksi tai useampi lapsi käytti alkoholia yksi-neljä annosta kerralla.

Matalasti koulutetut puolisot käyttivät tilastollisesti merkitsevästi suurempia määriä alkoholia kerralla kuin korkeasti koulutetut puolisot. Pelkän peruskoulun tai lukion suorittaneista puolisoista lähes viidennes ja ammatillisen tutkinnon suorittaneista puolisoista reilu kymmenesosa käytti kerralla vähintään 11 annosta alkoholia. Korkeasti koulutetuista puolisoista valtaosa käytti kerralla yksi-neljä alkoholiannosta. 


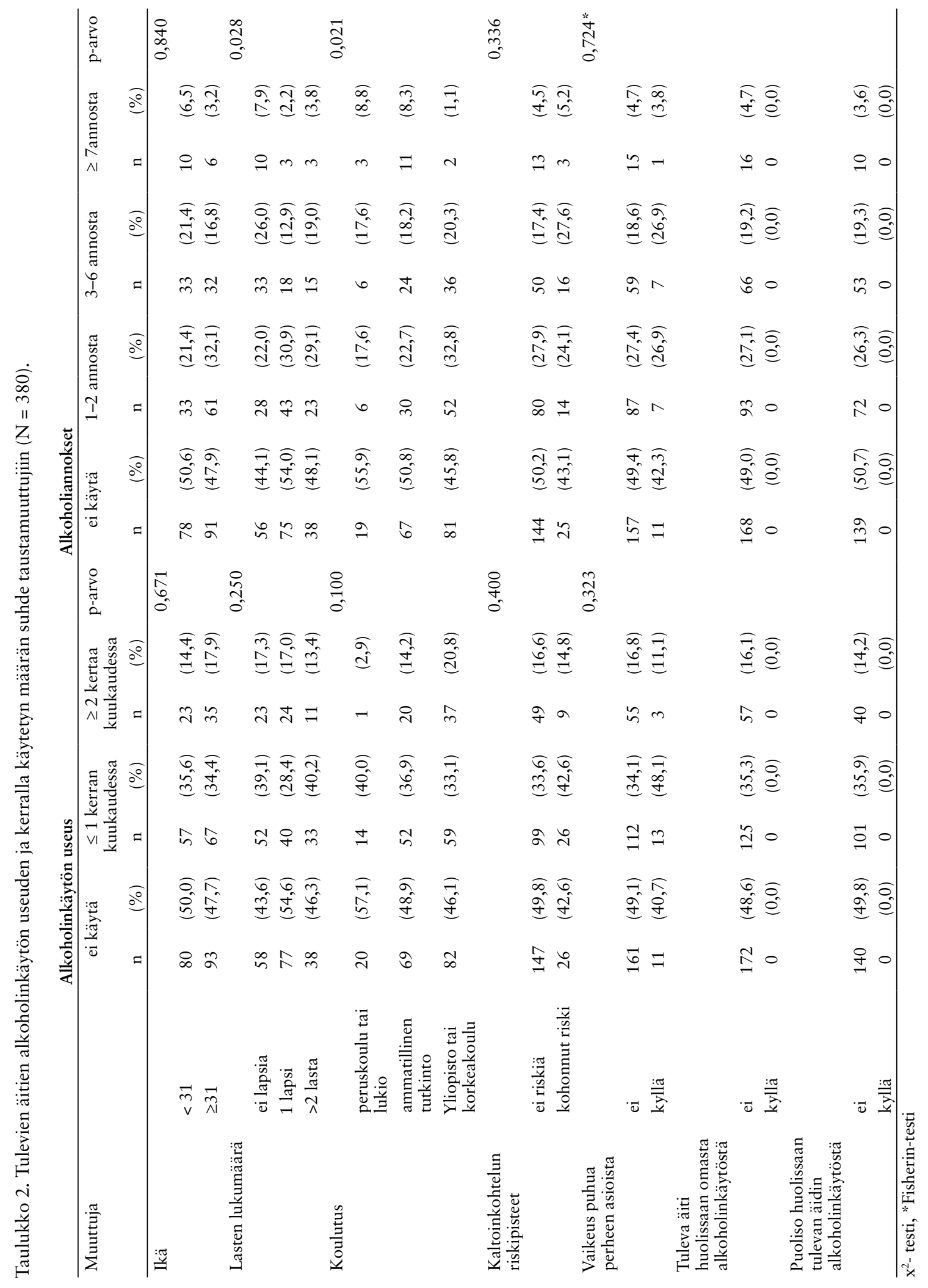




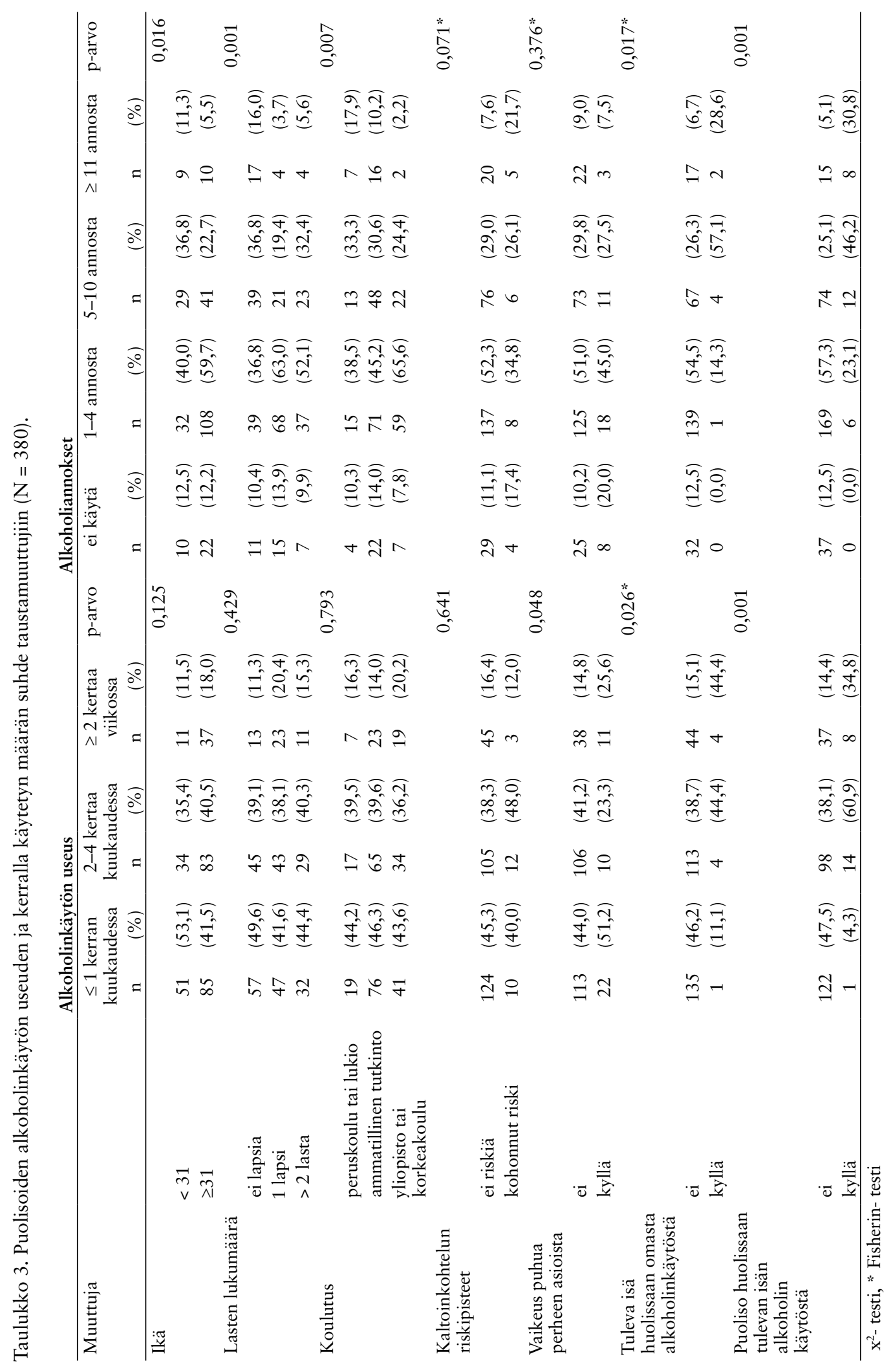


Alkoholin käyttökertojen määrässä ilmeni eroja sen suhteen, oliko puolisolla vaikeuksia puhua perheen asioista. Ero ryhmien välillä oli tilastollisesti merkitsevä. Yli kaksi kertaa viikossa alkoholia käyttävien osuus oli hieman suurempi niiden puolisoiden keskuudessa, joilla oli vaikeuksia puhua perheen asioista. Kaksi-neljä kertaa kuukaudessa alkoholia käyttävien osuus oli suurempi puolisoilla, joilla ei ollut vaikea puhua perheen asioista.

Omasta alkoholinkäytöstään huolestuneet puolisot käyttivät alkoholia tilastollisesti merkitsevästi useammin ja suurempia määriä kerralla kuin puolisot, jotka eivät kokeneet huolta omasta alkoholinkäytöstään. Yli puolet omasta alkoholinkäytöstään huolissaan olevista puolisoista käytti kerralla viisi-kymmenen annosta ja lähes kolmannes vähintään 11 annosta alkoholia kerralla.

Tulevien äitien huoli puolisoiden alkoholinkäytöstä oli niin ikään tilastollisesti merkitsevästi yhteydessä puolisoiden suurempiin kerralla käyttämiin alkoholimääriin ja siihen, kuinka usein puoliso käytti alkoholia. Lähes kaikki puolison alkoholinkäytöstä huolissaan olevat tulevat äidit raportoivat tulevan isän käyttävän alkoholia kaksi-neljä kertaa kuussa. Yli kolmannes huolissaan olevista tulevista äideistä raportoi puolison käyttävän alkoholia vähintään kaksi kertaa viikossa.

Lähes puolet huolissaan olevista tulevista äideistä raportoi tulevan puolison käyttävän alkoholia viisi-kymmenen annosta kerralla ja noin kolmasosa 11 annosta tai enemmän kerralla. Kaksi kertaa kuukaudessa tai useammin alkoholia käyttävät puolisot käyttivät alkoholia pienempiä kerta-annoksia kuin harvemmin alkoholia käyttävät puolisot. Taulukossa 3 on esitetty puolisoiden alkoholin käyttökertojen määrän ja kerralla käytetyn alkoholimäärän yhteys taustamuuttujiin.

\section{PUOLISON KUVAUS TULEVAN ÄIDIN ALKOHOLIN KÄYTÖSTÄ}

Kolmasosa puolisoista arvioi tulevan äidin alkoholin käyttökertojen määrän ja kerralla käytetyn alkoholimäärän samaksi kuin tuleva äiti itse. Vain hyvin pieni osa puolisoista arvioi tulevan äidin kerralla käyttämän alkoholimäärän merkittävästi pienemmäksi tai merkittävästi suuremmaksi kuin tuleva äiti oli itse ilmoittanut.
Puolisot, joilla oli kohonnut kaltoinkohtelun riski arvioivat muita puolisoja useammin äidin alkoholin käyttökertojen määrän merkittävästi äidin omaa ilmoitusta pienemmäksi $(\mathrm{p}=0,012)$. Taulukossa 4 on kuvattu puolison arvio tulevan äidin alkoholinkäytöstä ja arvion yhteys taustamuuttujiin.

\section{TULEVAN ÄIDIN KUVAUS PUOLISON ALKOHOLINKÄYTÖSTÄ}

Yli kaksi kolmannesta tulevista äideistä arvioi puolisonsa alkoholin käyttökertojen määrän samaksi kuin puoliso itse. Valtaosa heistä arvioi myös puolison kerralla käyttämän alkoholimäärän samaksi kuin puoliso itse. Hyvin pieni osa tulevista äideistä arvioi merkittävästi pienemmäksi tai merkittävästi suuremmaksi sen, kuinka usein ja kuinka paljon kerralla puoliso itse arvioi käyttävänsä alkoholia. Taulukossa 5 on kuvattu tulevan äidin arvio puolison alkoholinkäytöstä ja arvion yhteys taustamuuttujiin.

\section{POHDINTA}

\section{TULOSTEN TARKASTELU}

Tutkimuksen avulla saatiin ajankohtaista tietoa vähän tutkitusta aiheesta eli suomalaisten vanhempien alkoholinkäytöstä tulevan äidin raskausaikana. Yli puolet odottavista naisista käytti alkoholia raskausaikana. Määrä on suurempi kuin aiemmissa raskaana olevien naisten alkoholinkäyttöä kartoittavissa tutkimuksissa, joissa 5,5-45,0 prosenttia naisista jatkoi alkoholinkäyttöä raskausaikana (26-33). Tiedossa on, että naisten alkoholinkäyttö on lisääntynyt ja että yli 90 prosenttia hedelmällisessä iässä olevista naisista käyttää alkoholia (12).

Aiempien tutkimusten tapaan myös tässä tutkimuksessa suurin osa alkoholia raskausaikana käyttävistä naisista käytti alkoholia vain harvoin ja pieniä määriä kerralla (26-33). Kuitenkin jopa neljännes kaikista tulevista äideistä käytti alkoholia vähintään kolme annosta kerralla ja lähes viisi prosenttia käytti alkoholia vähintään seitsemän annosta kerralla. Alkoholia raskausaikana käyttävien naisten osuus oli tutkimuksessa yllättävän suuri, kun otetaan huomioon, että viralliset ohjeistukset kehottavat tulevia äitejä pidättäytymään raskaudenaikaisesta alkoholinkäytöstä kokonaan $(38,39,44,45)$. 


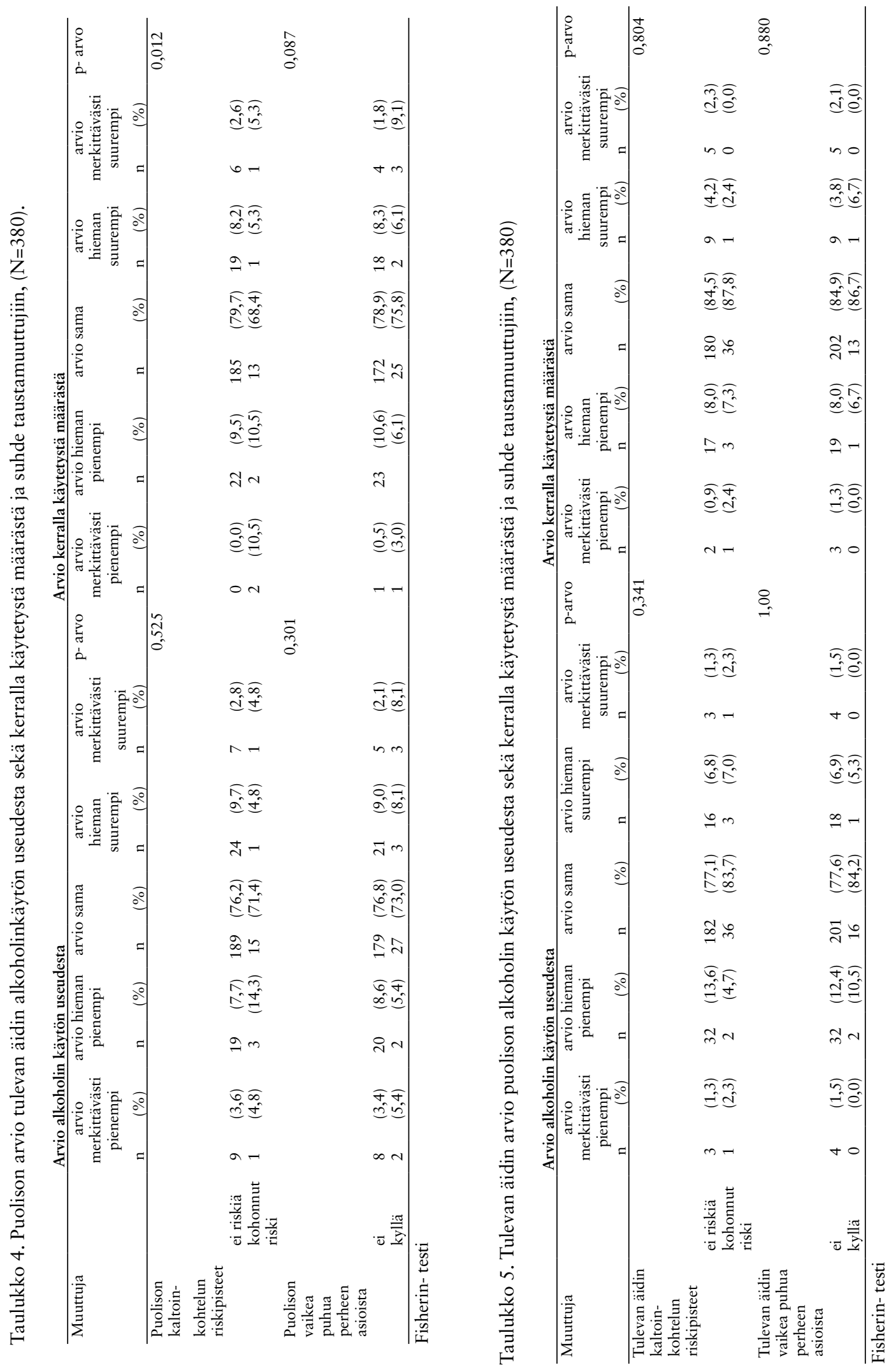


Törrönen ja Tryggvesson (46) toteavat artikkelissaan, että tuleville äideille suunnatut julkisen terveydenhuollon kampanjat ja ohjeistukset koetaan naisten keskuudessa etäisiksi keinoiksi vaikuttaa tulevien äitien raskaudenaikaiseen käyttäytymiseen. Täydelliseen absolutismiin velvoittavat ohjeistukset koetaan tulevien äitien keskuudessa naisten itsemääräämisoikeutta polkeviksi, holhoaviksi ja moralisoiviksi (47).

Holland kollegoineen (48) on tutkimuksessaan selvittänyt naisten asenteita raskaudenaikaiseen alkoholinkäyttöön. Valtaosa tutkimukseen osallistuneista naisista ei uskonut, että kohtuullinen ja satunnainen alkoholinkäyttö voisi vaarantaa sikiön terveen kehityksen, koska yksiselitteistä näyttöä kohtuullisen alkoholinkäytön vaikutuksesta sikiön kehitykseen ei ole $(17,18)$. Tutkimuksen naiset eivät kuitenkaan hyväksyneet humalahakuista alkoholinkäyttöä raskausaikana. Naiset uskoivat, että runsas raskaudenaikainen humalahakuinen alkoholinkäyttö on oire tulevan äidin muista ongelmista eikä merkki huonosta tai välinpitämättömästä vanhemmuudesta. (48.)

Tässä tutkimuksessa runsaasti alkoholia käyttävien naisten osuus oli viisi prosenttia kaikista tulevista äideistä. Yksikään tuleva äiti tai puoliso ei silti kokenut olevansa huolissaan raskaana olevan naisen alkoholinkäytöstä. Perheissä, joissa tuleva isä käytti alkoholia usein tai suuria määriä kerralla, myös tuleva äiti käytti alkoholia useammin ja suurempia määriä kerralla kuin muut tulevat äidit. Yhteys oli tilastollisesti merkitsevä $(p=0,001)$. Alkoholiriippuvuuteen kuuluu usein se, että henkilö ei tunnista ongelmaansa tai kieltää sen. Voikin olla, että vanhemmille, jotka eivät kokeneet huolta tulevan äidin mittavasta raskaudenaikaisesta alkoholin käytöstä, oli jo kehittynyt alkoholiongelma. (49.)

Puolisoiden alkoholinkäyttö oli tässä tutkimuksessa melko yhdenmukaista THL:n vuoden 2008 kyselyn kanssa, jossa kymmenen prosenttia miehistä oli raittiita ja kahdeksan prosenttia ylitti alkoholin suurkulutuksen rajan (4). Puolisoista lähes puolet käytti alkoholia satunnaisesti eli korkeintaan kerran kuukaudessa ja yli puolet käytti alkoholia kerralla kohtuullisesti eli yksineljä annosta. Usein (kaksi kertaa kuukaudessa tai useammin) alkoholia käyttävistä puolisoista valtaosa käytti kerralla pieniä määriä alkoholia. Tutkimuksessa alkoholin kohtuukäyttäjien osuus on melko suuri, ja vain pieni osa vastaajista on alkoholin suurkuluttajia. THL:n raportti vuodelta 2013 osoittaa, että suomalaisten alkoholinkäyttö jakaantuu hyvin epätasaisesti ja että niin naisilla kuin miehillä eniten alkoholia käyttävien kymmenys kuluttaa noin puolet kaikesta alkoholista (4).

Tässä tutkimuksessa ei pystytty selvittämään, miten tulevien isien alkoholinkäyttötottumukset muuttuvat puolison raskausaikana, koska kyselyssä ei selvitetty vastaajien raskausaikaa edeltävää alkoholinkäyttöä. Törrönen ja Tryggvesson (46) toteavat artikkelissaan, että virallisissa raskausajan ohjeistuksissa tulevan isän rooli on jätetty lähes huomiotta, vaikka tulevalla isällä on keskeinen rooli sikiön suojelussa ja nykypäivänä vanhemmuus ja lapsen kasvun turvaaminen koetaan yhä enenevästi molempien vanhempien tehtäväksi.

Vanhempien kerralla käyttämä alkoholimäärä väheni lasten saannin myötä. Raskaana olevat naiset, joilla ei ollut aiempia lapsia, käyttivät alkoholia suurempia määriä kerralla kuin naiset, joilla oli jo yksi tai useampi lapsi. Tulos ei ole yllättävä, mutta se on päinvastainen aiempien tutkimustulosten kanssa, joissa perheen lasten suurempi lukumäärä oli yhteydessä tulevan äidin runsaampaan raskaudenaikaiseen alkoholinkäyttöön $(26,28,33)$. Myös puolisoiden kerralla käyttämä alkoholimäärä väheni huomattavasti lasten saannin myötä. Nuoremmat isät käyttivät kerralla suurempia määriä alkoholia kuin vanhemmat isät. Tulevan äidin ikä ei aiemmista tutkimuksista $(28,30,31,33)$ poiketen vaikuttanut raskaudenaikaiseen alkoholinkäyttöön.

Mäkelä ja Härkönen (50) ovat artikkelissaan todenneet, että perheellistyminen ja lasten saanti vähentävät niin miesten kuin naisten tarvetta juhlimiseen ja parinhakuun, mikä näkyy vähentyneenä alkoholinkäyttönä. Tulosta arvioitaessa on hyvä ottaa huomioon, että suomalaisten naisten alkoholinkulutus on kuusinkertaistunut viimeisen 40 vuoden aikana ja että tämän myötä myös hedelmällisessä iässä olevien naisten alkoholinkäyttö on lisääntynyt $(4,6)$. Voikin olla, että alkoholin käytön arkipäiväistymisen ja erityisesti naisten lisääntyneen alkoholinkulutuksen myötä naisten voi olla haastavaa jättää alkoholi pois elämästään ensimmäisen raskauden aikana, mikä näkyy suurempina kerralla käytettyinä alkoholimäärinä ensimmäistä lastaan odottavilla nai- 
silla. Aiempien lasten lukumäärä ei vaikuttanut tilastollisesti merkitsevästi tulevien vanhempien alkoholin käyttökertojen määriin.

Matala koulutustausta oli yhteydessä suurempiin kerralla käytettyihin alkoholimääriin sekä tulevilla äideillä että heidän puolisoillaan. Tulevien äitien kohdalla tulos on päinvastainen aiempien tutkimusten $(28,31-34)$ kanssa, joissa korkeasti koulutetut naiset kuluttivat muita naisia suurempia määriä alkoholia raskausaikana. Puolisoiden kohdalla tulos on yhtenevä Hyssälän ja kollegoiden (34) sekä Terveyden ja hyvinvointilaitoksen (4) tutkimustulosten kanssa, joissa miesten matala koulutustausta oli yhteydessä suurempiin kerralla käytettyihin alkoholimääriin. On kuitenkin hyvä huomioida, että raittiiden osuus oli pienin korkeasti koulutettujen ryhmässä sekä äitien että puolisoiden osalta. Kauppisen (51) tutkimus tukee tätä tulosta. Raittiista suomalaisista suurimmalla osalla on matala koulutustausta. Tässä tutkimuksessa ei ilmennyt koulutustaustan yhteyttä vanhempien alkoholin käyttökertojen määrään.

Vähintään kaksi kertaa viikossa alkoholia käyttävien osuus oli suurempi puolisoilla, joiden oli vaikea puhua perheen asioista. Vallalla on käsitys, että miesten on perinteisesti hankalampaa puhua vaikeista asioista tai tunteistaan ulkopuoliselle kuin naisten. Alkoholilla taas on tunnetusti rentouttava ja estoja poistava vaikutus (52). On mahdollista, että miehet, jotka kokivat vaikeaksi puhua perheen asioista, käyttivät alkoholia useammin rohkaistumisen välineenä.

Yli puolet tulevista vanhemmista arvioi toistensa alkoholin käyttökertojen määrän ja kerralla käytetyn alkoholimäärän samaksi. Niin tulevien äitien kuin puolisoidenkin ryhmässä vain hyvin pieni osa vastaajista arvioi alkoholin käyttökertojen määrän ja kerralla käytetyn alkoholimäärän merkittävästi pienemmäksi tai merkittävästi suuremmaksi. Tulosta arvioitaessa on kuitenkin hyvä huomioida luokkien pienet frekvenssit.

\section{TUTKIMUKSEN EETTISYYS}

Tutkimusaiheen valinnassa pohdittiin erityisesti aiheen oikeutusta, koska kyseessä on arkaluonteinen tutkimusaihe (53). Tutkimuksen myötä tuotettava tieto on kuitenkin yhteiskunnallisesti merkittävää ja ajankohtaista, koska sekä suomalaisten naisten että miesten alkoholinkäyttö on lisääntynyt viimeisten vuosikymmenten aikana ja samalla myös raskaudenaikaisen alkoholinkäytön aiheuttamat sikiövauriot ovat lisääntyneet. $(4,5$.)

Tutkimukseen osallistuminen oli vapaaehtoista. Osallistujille kerrottiin selkeästi tutkimuksen toteutuksesta ja siitä, mihin tietoja käytetään. Kyselyt kerättiin nimettöminä ja aineistoa käsiteltiin anonyymisti. Alkoholin käyttöä selvittävässä osatutkimuksessa käytettiin valmista aineistoa, joten tutkijalla ei ollut henkilökohtaista suhdetta neuvoloihin tai tutkimuksen osallistujiin. Tämä lisää tutkimuksen objektiivisuutta. (54.)

Koko tutkimusprosessi toteutettiin hyvät tieteelliset käytännöt huomioiden. Tulosten tallentamisessa ja esittämisessä pyrittiin rehellisyyteen ja yleiseen huolellisuuteen. Koko tutkimusprosessin ajan noudatettiin tieteellisen tiedon kriteerien mukaisesti avoimuutta: tutkimus suunniteltiin, toteutettiin ja raportoitiin yksityiskohtaisesti. Muiden tutkijoiden tekemää työtä kunnioitettiin käyttämällä asianmukaisia viittauksia, kun hyödynnettiin muiden julkaisuja. Tutkimuksella on Pirkanmaan sairaanhoitopiirin eettisen toimikunnan puoltava lausunto (55).

\section{TUTKIMUKSEN LUOTETTAVUUS}

Tutkimuksessa käytettiin kahta jo olemassa olevaa mittaria. Vanhempien raskaudenaikaista alkoholinkäyttöä kartoitettiin AUDIT-kyselyllä, joka on Maailman terveysjärjestö WHO:n kehittämä, maailmanlaajuisessa käytössä oleva testi. AUDIT-testin luotettavuus on arvioitu useassa lähteessä hyväksi (56.) Tulevien vanhempien todennäköisyyttä kohdella lastaan kaltoin kartoitettiin Child Abuse Potential Inventory (CAP) -mittarilla, joka on paljon käytetty mittari kaltoinkohteluriskin seulonnassa (40,57). Myös CAP-mittarin luotettavuus on osoitettu hyväksi $(42,58)$.

Osa vastaajista vastasi kyselyyn neuvolassa ja palautti lomakkeen välittömästi terveydenhoitajalle, ja osa täytti kyselyn kotona ja palautti sen postitse. Puolisoiden vastaukset lähetettiin pääsääntöisesti kotoa. Vanhemmat vastasivat pääosin kyselyyn itsenäisesti eivätkä olleet tietoisia toistensa vastauksista. Tämä lisää tutkimuksen luotettavuutta. Alkoholinkäyttöä kartoittavat kysymykset olivat kyselylomakkeessa osana taustakysymyksiä. Tämän voidaan olettaa lisäävän kysymysten luettavuutta ja tämän myötä tutkimuksen luotettavuutta.

Aineisto kerättiin kahdelta suomalaiselta 
paikkakunnalta. Kyselyn peittoalueella syntyy vuosittain noin 1400 lasta. Kyselyyn vastasi 380 perhettä, joten tutkimuksen otoksen edustavuus on noin 27 prosenttia. Tutkimuksen luotettavuutta ja tilastollista yleistettävyyttä rajoittavana tekijänä voidaan pitää sitä, että kaikki tutkimukseen osallistuneet henkilöt olivat kahdelta paikkakunnalta. Tästä johtuen tutkimustulosten yleistämiseen koko Suomen populaatioon tulee suhtautua harkiten. (53.)

Oman alkoholinkulutuksen arviointi on tunnetusti alimitoitettua $(59,60)$. Myös raskaudenaikaisen alkoholinkäytön itsearviointi on usein alimitoitettua (40). Tämä on yksi tutkimuksen luotettavuutta rajoittava tekijä, ja se on hyvä huomioida tutkimustuloksia arvioitaessa. Tutkimuksen luotettavuutta arvioitaessa on myös syytä huomioida epätarkkuus vastaajan ja hänen puolisonsa kerralla käyttämää alkoholimäärää kartoittavassa kysymyksessä. Vastaajaa pyydettiin kyselylomakkeessa kertomaan, kuinka monta annosta alkoholia vastaaja itse ja hänen puolisonsa yleensä nauttii kerralla. Kysymys on mahdollista ymmärtää väärin tarkoittamaan aikaa ennen raskautta. Toisaalta aineisto kerättiin loppuraskauden aikana. Kyselyssä ei myöskään määritelty, mitä alkoholiannoksella tarkoitetaan. Myös tämä on tutkimuksen luotettavuutta rajoittava tekijä.

\section{JOHTOPÄÄTÖKSET}

Yli puolet naisista käyttää alkoholia raskausaikana. Vaikka valtaosa tulevista äideistä käyttää alkoholia vain harvoin ja pieniä määriä kerralla, jopa neljännes tulevista äideistä käyttää kerralla vähintään kolme annosta alkoholia. Tulevat äidit ja isät eivät koe huolta tulevan äidin runsaastakaan raskaudenaikaisesta alkoholinkäytöstä, mutta puolison runsas alkoholinkäyttö koetaan huolestuttavaksi niin raskaana olevien naisten kuin puolisoiden itsensä keskuudessa. Noin puolet raskaana olevien naisten puolisoista käyttää alkoholia kerralla kohtuullisesti, kun taas yli kolmannes käyttää kerralla vähintään viisi annosta alkoholia. Puolisoista yli 12 prosenttia on raittiita.

Vanhempien kerralla käyttämä alkoholimäärä pienenee merkittävästi perheen perustamisen myötä. Korkeasti koulutetut tulevat äidit ja puolisot kuluttavat kerralla pienempiä määriä alkoholia kuin vähemmän koulutetut, mutta suurimmalla osalla raittiista tulevista vanhemmista on matala koulutustaso. Tulevien vanhempien arviot toistensa alkoholinkäytöstä tulevan äidin raskausaikana vastaavat pääsääntöisesti hyvin toisiaan. Vanhempien kanssa on tärkeä keskustella alkoholinkäytöstä, sen vaikutuksista lapsiin ja mahdollisista haitoista lapselle ja perheen arjelle esimerkiksi neuvolassa, jossa lähes kaikki perheet asioivat.

Lasta odottavien vanhempien raskaudenaikaista alkoholinkäyttöä tulisi tutkia laajemmin Suomessa. Olisi myös mielenkiintoista selvittää, miksi suomalaiset äidit käyttävät alkoholia raskausaikana, vaikka viralliset ohjeistukset neuvovat naisia pidättäytymään alkoholista raskausaikana.

\section{KIRJOITTAJIEN KONTRIBUUTIOT:}

Artikkelikäsikirjoitus on osa Komulaisen Pro Gradu -tutkielmaa ja Komulainen on toiminut tutkimusprosessin toteuttajana ja käsikirjoituksen kirjoittajana. Lepistö, Kylmä ja Paavilainen ovat toimineet pro gradu -tutkielman ohjaajina. Helminen puolestaan on ohjannut Komulaista tutkimuksen tilastollisissa analyyseissa.

Komulainen, J., Lepistö, S., Helminen, M., Kylmä, J., Paavilainen, E. Alcohol use of expectant parents during pregnancy. Sosiaaliläaketieteellinen aikakauslehti - Journal of Social Medicine 2017:54: 269-284.

This research describes the alcohol consumption of expectant parents during pregnancies. From the research material, we selected data focusing on the alcohol consumption of mothers and their spouses. In total, 380 families took part in the survey. The material was processed using cross-tabulation and described using statistical frequencies and percentages. Over half of the pregnant moth- ers consumed alcohol during pregnancy. The majority consumed alcohol infrequently and in small amounts, although almost a quarter consumed at least three alcohol units on each occasion. Almost five percent of the expectant mothers drank heavily during pregnancy. The majority of the spouses consumed alcohol moderately. Almost half consumed alcohol at most once a month, and slight- 
ly over half consumed one to four units during each occasion. About seven percent drank alcohol heavily and slightly over 12 percent of the spouses abstained totally. The expectant parent couple's evaluations of each other's alcohol consumption were fairly similar. It is important to discuss the consumption of alcohol with parents, and effects it may have on their children and daily family life. Prenatal clinic appointments are one possible place for such discussions. The alcohol consumption of pregnant mothers should also be examined more closely in Finland, in particular to examine why Finnish women consume alcohol during pregnancy, even though official guidelines instruct mothers not to do so.

Keywords: family with kids, use of alcohol, pregnancy

\section{LÄHTEET}

(1) Karlsson T. Finnish, Norwegian and Swedish alcohol policy after the seminal year of 2004 . Nordisk Alkohol Nark 2008; 25: 205-222.

(2) Mäkelä K. Alkoholin käytön viikkorytmi ennen ja jälkeen lainuudistuksen. Alkoholipolitiikka 1970; 35: 128-134.

(3) Härkönen J, Österberg E. Miten alkoholiin on suhtauduttu ennen ja nyt? Kirjassa: Suomi juo. Suomalaisten alkoholinkäyttö ja sen muutokset 1968-2008. Helsinki: Terveyden ja hyvinvoinnin laitos; 2010, 155-166.

(4) Karlsson T, Kotovirta E, Tigerstedt C. (toim.). Alkoholi Suomessa. Kulutus, haitat ja politiikkatoimet. Raportti 13..Helsinki: Terveyden ja hyvinvoinnin laitos; 2013.

(5) Terveyden ja hyvinvoinnin laitos. Alkoholijuomien kulutus 2015. Luettu 10.12.2016. https://www.thl.fi/fi/tilastot/tilastotaiheittain/paihteet-ja-riippuvuudet/alkoholi/ alkoholijuomien-kulutus.

(6) Mäkelä P, Mustonen H, Huhtanen P. Alkoholinkäyttötapojen muutokset 1968-2008. Kirjassa: Mäkelä P, Mustonen H, Tigerstedt C. Suomi juo. Suomalaisten alkoholinkäyttö ja sen muutokset 1968-2008. Helsinki: Terveyden ja hyvinvoinnin laitos; 2010, 39-54.

(7) Autti-Rämö I. On aika tehdä päätöksiä. Alkoholin aiheuttamat sikiövauriot lisääntyvät. Duodecim 2011; 127: 1634-1636.

(8) Riley E, Infante M, Warren K. Fetal alcohol spectrum disorders: an overview. Neuropsychol Rev 2011; 21: 73-80. https://doi.org/10.1007/s11065-011-9166-x

(9) May PA, Gossage JP, Kalberg WO, ym. Prevalence and epidemiologic characteristics of FASD from various research methods with an emphasis on recent in-school studies. Dev Disabil Res Rev 2009; 15: 176-92. https://doi.org/10.1002/ddrr.68

(10) Thanh NX, Jonsson E, Salmon A, ym. Incidence and prevalence of fetal alcohol spectrum disorder by sex and age group in Alberta, Canada. J Popul Ther Clin Pharmacol 2014; 21 : 395-404.

(11) May PA, Baete A, Russo J, ym. Prevalence and characteristics of fetal alcohol spectrum disorders. Pediatrics 2014; 134: 855-66. https://doi.org/10.1542/peds.2013-3319

(12) Autti-Rämö I, Fagerlund Å, Korkman M. Miten tunnistat sikiön alkoholivauriot. Suom Lääkäril 2008; 63: 501-506.

(13) Streissguth AP, Bookstein FL, Barr HM, ym. The Long-Term Neurocognitive Consequences of Prenatal Alcohol Exposure: A 14-Year Study. Psychol Sci 1999; 10: 186-190. https://doi.org/10.1111/1467-9280.00131

(14) Flak AL, Su S, Bertrand J, ym. The association of mild, moderate, and binge prenatal alcohol exposure and child neuropsychological outcomes: a meta-analysis. Alcohol Clin Exp Res 2014; 38: 214-26. https://doi.org/10.1111/acer.12214

(15) Ernhart CB, Sokol RJ, Martier S, ym. Alcohol teratogenicity in the human: a detailed assessment of specificity, critical period, and threshold. Am J Obstet Gynecol 1987; 156: 33-39. https://doi.org/10.1016/0002-9378(87)90199-2

(16) Astley SJ. Profile of the first 1400 patients receiving diagnostic evaluations for fetal alcohol spectrum disorder at the Washington State Fetal Alcohol Syndrome Diagnostic \& Prevention Network. Can J Clin Pharmacol 2010; 17: 132-64.

(17) Henderson J, Gray R, Brocklehurst P. Systematic review of effects of low-moderate prenatal alcohol exposure on pregnancy outcome. BJOG 2007; 114: 243-245. https://doi.org/10.1111/j.14710528.2006.01163.x

(18) O Keeffe L, Greene R, Kearney P. The effect of moderate gestational alcohol consumption during pregnancy on speech and language outcomes on children: a systematic review. BioMed Central 2014; 3.

(19) Niemelä S, Niemelä O, Ritvanen A, ym. Fetal alcohol syndrome and maternal alcohol biomarkers in sera: a register-based casecontrol study. Alcohol Clin Exp Res 2016; 40: 1507-1514. https://doi.org/10.1111/acer.13101

(20) Patra J, Bakker R, Irving H, ym. Dose-response relationship between alcohol consumption before and during pregnancy and the risks of low birthweight, preterm birth and small for gestational age (SGA)-a systematic review and 
meta-analyses. BJOG 2011; 118: 1411-1421.

https://doi.org/10.1111/j.1471-

0528.2011.03050.x

(21) Rodriguez A, Olsen J, Kotimaa AJ, ym. Is prenatal alcohol exposure related to inattention and hyperactivity symptoms in children? Disentangling the effects of social adversity. J Child Psychol Psychiatry 2009; 50: 1073-1083. https://doi.org/10.1111/j.1469-

7610.2009.02071.x

(22) Shankar K, Hidestrand M, Liu X, ym. Physiologic and genomic analyses of nutritionethanol interactions during gestation: Implications for fetal ethanol toxicity. Exp Biol Med 2006; 231: 1379-1397.

https://doi.org/10.1177/153537020623100812

(23) Vaarla S. Johdanto: alkoholialtistuksen vaikutukset lapsen elämään. Kirjassa: Vaarla S. Alkoholin vaurioittamat. Raskaudenaikaisen alkoholinkäytön vaikutukset lapsen elämään. Helsinki: Kehitysvammaliitto ry; 2011, 7-24.

(24) Nordström T, Hurtig T, Rodriguez A, ym. Different risk factors between disruptive behavior disorders and ADHD in Northern Finland birth cohort1986. J Atten Disord 2014; 7: 1-9.

(25) Pajulo M, Savonlahti E, Sourander A, ym. Antenatal depression, substance depency and social support. J Affect Disord 2000; 65: 9-17. https://doi.org/10.1016/S0165-0327(00)00265-2

(26) Comasco E, Hallberg G, Helander A, ym. Alcohol consumption among pregnant women in a Swedish sample and its effects on the newborn outcomes. Alcohol Clin Exp Res 2012; 36: 1779-1786.

https://doi.org/10.1111/j.15300277.2012.01783.x

(27) Göransson M, Magnusson Å, Bergman H, ym. Fetus at risk: prevalence of alcohol consumption during pregnancy estimated with a simple screening method in Swedish antenatal clinics. Addiction 2003; 98: 1513-1520.

https://doi.org/10.1046/j.13600443.2003.00498.x

(28) Lanting C, Caren I, van Dommelen P, ym. Prevalence and pattern of alcohol consumption during pregnancy in the Netherlands. BMC Public Health 2015; 15: 723. https://doi.org/10.1186/s12889-015-2070-1

(29) Pfinder M, Kunst A, Feldmann R, ym. Educational differences in continuing or restarting drinking in early and late pregnancy: role of psychological and physical problems. J Stud Alcohol Drugs 2014; 75: 47-55. https://doi.org/10.15288/jsad.2014.75.47

(30) Skageström J, Alehagen S, Haggström-Nordin E, ym. Prevalence of alcohol use before and during pregnancy and predictors of drinking during pregnancy: a cross sectional study in Sweden. BMC Public Health 2013; 13: 780. https://doi.org/10.1186/1471-2458-13-780

(31) Van der Wulp N, Hoving C, de Vries H. Partner's influences and other correlates of prenatal alcohol use. Maternn Child Health
J 2015; 19: 908-916. https://doi.org/10.1007/s10995-014-1592-y

(32) Andersen A-M, Adersen PK, Olsen J, ym. Moderate alcohol intake during pregnancy and risk of fetal death. Int J Epidemiol 2012; 1-9.

(33) Skageström J, Chang G, Nilsen P. Predictors of drinking during pregnancy: a systematic review. J Womens Health 2011; 20: 901-913. https://doi.org/10.1089/jwh.2010.2216

(34) Hyssälä L, Rautava P, Sillanpää M, ym. Changes in the smoking and drinking habits of future fathers from the onset of their wives' pregnancies. J Adv Nurs 1992; 17: 849-854. https://doi.org/10.1111/j.1365-2648.1992. tb02007.x

(35) Freisthler B, Holmes M, Wolf J. The dark side of social support: understanding the role of social support, drinking behaviors and alcohol outlets for child physical abuse. Child Abuse Negl 2014; 38: 1106-1119. https://doi.org/10.1016/j.chiabu.2014.03.011

(36) Smith D, Johanson A, Pears K, ym. Child maltreatment and foster care: unpacking the effects of prenatal and postnatal parental substance use. Child maltreat 2007; 12 : 150-160. https://doi.org/10.1177/1077559507300129

(37) Berger L. Income, family characteristics, and physical violence toward children. Child Abuse Negl 2005; 29: 107-133. https://doi.org/10.1016/j.chiabu.2004.02.006

(38) Klemetti R, Hakulinen-Viitanen T (toim.). Äitiysneuvolaopas. Suosituksia äitiysneuvolatoimintaan. Tampere: Terveyden ja hyvinvoinnin laitos; 2013.

(39) Duodecim. Käypä hoito. Suositukset. Alkoholiongelmaisen hoito. Audit- kysely. 2015. Luettu 3.3.2016. http://www.terveysportti.fi/ xmedia/hoi/hoi50028b.pdf

(40) Tarnanen K, Alho H, Komulainen J. Alkoholiongelmaisen hoito. Käyvän hoidon potilasversiot. Suomalainen lääkäriseura Duodecim; 2015. Luettu 3.3.2016. http://www. terveyskirjasto.fi/terveyskirjasto/tk.koti?p_ artikkeli=khp00049\&phaku=alkoholi \% 20 ja\%20raskaus.

(41) Milner J. Assessing physical child abuse risk: The child abuse potential inventory. Clin Psychol Rev 1994; 14: 547-583. https://doi.org/10.1016/0272-7358(94)90017-5

(42) Ellonen N, Lepistö S, Helminen M, ym. Crosscultural validation of the Child Abuse Potential Inventory in Finland: Preliminary findings of the study among parents expecting a baby. Journal of Social Service Research 2017; 43: 308-318. http://dx.doi.org/10.1080/01488376.2017.1295 008 .

(43) Nummenmaa L. Käyttäytymistieteiden tilastolliset tutkimusmenetelmät. Helsinki: Tammi; 2010.

(44) Tïtinen A. Raskaus ja alkoholi. Lääkärikirja Duodecim. 2015. Kustannus Oy Duodecim; 2015. Luettu 17.3.2016. 
(45) Leppo A, Hecksher D. The rise of the total abstinence model. Recommendations regarding alcohol use during pregnancy in Finland and Denmark. Nordic Studies on Alcohol and Drugs 2011; 28: 7-27. https://doi.org/10.2478/v10199-011-0002-7

(46) Törrönen J, Tryggvesson K. Alcohol, health and reproduction. An analysis of Swedish public health campaigns against drinking during pregnancy. Critical Discourse Studies 2015; 12: 57-77. https://doi.org/10.1080/17405904.2014.934386

(47) Lowe PK, Lee EJ. Advocating alcohol abstinence to pregnant women: Some observations about British policy. Health Risk Soc 2010; 12: 301-311. https://doi.org/10.1080/13698571003789690

(48) Holland K, McCallum K, Walton A. I'm not clear on what the risk is`: women's reflexive negotiations of uncertainty about alcohol during pregnancy. Health Risk Soc 2016; 18: 35-58. https://doi.org/10.1080/13698575.2016.1166186

(49) Huttunen M. Alkoholiriippuvuus (Alkoholismi). Lääkärikirja Duodecim. 2015. Kustannus Oy Duodecim. Luettu 27.3.2016 http://www. terveyskirjasto.fi/terveyskirjasto/tk.koti?p_ artikkeli=dlk00196.

(50) Mäkelä P, Härkönen J. Miten juominen muuttuu iän myötä? Kirjassa: Mäkelä P, Mustonen H, Tigerstedt C. Suomi juo. Suomalaisten alkoholinkäyttö ja sen muutokset 1968-2008. Helsinki: Terveyden ja hyvinvoinnin laitos; 2010, 115-127.

(51) Kauppinen T. Voiko juomari hyvin? Kirjassa: Mäkelä P, Mustonen H, Tigerstedt C. Suomi juo. Suomalaisten alkoholinkäyttö ja sen muutokset 1968-2008. Helsinki: Terveyden-ja hyvinvoinninlaitos; 2010, 207-219.

(52) Poikolainen K. Alkoholihumala ja muita alkoholin välittömiä vaikutuksia. Kirjassa: Lääkärikirja Duodecim. Kustannus Oy Duodecim. Luettu 24.3.2016. http://www. terveyskirjasto.fi/terveyskirjasto/tk.koti?. artikkeli=dlk01084.

(53) Ronkainen S, Pehkonen L, Lindblom-Ylänne S. Tutkimuksen voimasanat. 1.-2. painos. Helsinki: Sanoma Pro Oy. 2013.

(54) Kankkunen P, Vehviläinen-Julkunen K. Tutkimus hoitotieteessä. Helsinki: WSOYPro. 2009.

(55) Tutkimuseettinen neuvottelukunta. Hyvä tieteellinen käytäntö. 2012. Luettu 23.3.2016. http://www.tenk.fi/fi/htk-ohje/hyva-tieteellinenkaytanto.

(56) de Meneses-Gaya C, Zuardi A, Loureiro S, ym. Alcohol use disorders identification test (AUDIT): an updated systematic review of psychometric properties. Psychol Neurosci 2009; 2: 83-97. https://doi.org/10.3922/j.psns.2009.1.12

(57) Sacchi C, Simonelli A. The child abuse potential (CAP) inventory. applications from 1986 to 2014. Advanced Research in Scientific Areas 2014; 12: 205-210.

(58) Milner J, Gold R, Wimberley R. Prediction and explanation of child abuse: cross-validation of the child abuse potential inventory. J Consult Clin Psychol 1986; 54: 865-866. https://doi.org/10.1037/0022-006X.54.6.865

(59) Mäkelä P, Mustonen H. Koskevatko juomisen riskit vain pientä vähemmistöä? Kirjassa: Mäkelä P, Mustonen H, Tigerstedt C. Suomi juo. Suomalaisten alkoholinkäyttö ja sen muutokset 1968-2008. Helsinki: Terveyden ja hyvinvoinnin laitos; 2010, 195-206.

(60) Barrow M, Riley E. Diagnosis of fetal alcohol syndrome: emphasis on early detection. Kirjassa: Preece P, Riley E. Alcohol, drugs and medication in pregnancy: the long term outcome for the child. UK: Mac Keith Press: 2010; 83-107.

\section{Jenni Komulainen \\ $T t M$}

Tampereen yliopisto

Terveystieteiden yksikkö

Apulaisosastonhoitaja

Helsingin- ja Uudenmaan sairaanhoitopiiri

\section{SARI LEPISTÖ \\ TtT, ylihoitaja \\ Pirkanmaan sairaanhoitopiiri \\ Tampereen yliopisto \\ Terveystieteiden yksikkö}

\section{Mika Helminen \\ FM, biostatistikko \\ Tampereen yliopisto \\ Terveystieteiden yksikkö}

\section{JARI KYLMÄ}

FT, dosentti, yliopistonlehtori

Tampereen yliopisto

Terveystieteiden yksikkö

Eija PaAvilainen

TtT, professori

Tampereen yliopisto

Terveystieteiden yksikkö 